\title{
LABOUR, SOCIAL REPRODUCTION AND THE TIME OF LAW
}

Henrique Weil Afonso ${ }^{1}$

\section{Abstract}

The aim of this paper is to develop a historical scrutiny of the interplay between legal regulation and social reproduction. The question of marketization of the social sphere has been gaining significant attention over the past decades. While social theorists update Polanyian analysis of the status of embedded and disembedded markets to understand present-day crisis of social reproduction, it is relevant to situate these in light of historical lenses. By focusing on the idea of uberization of labour and care work, it considers, in the first case, how contemporary forms of labour are detrimental to the maintenance of the social fabric and, in the second one, how long-standing forms of violence are reproduced. It develops an argument according to which the disruption of work-related regulation has a direct connection to the inability of legal systems to institutionalize proper social times that are not reducible to market time.

\section{Keywords}

Legal history. Labour. Law and society. Market regulation.

\section{Summary}

1. Introduction. 2. Contextualizing social-legal critique in times of crises. 2.1 The present of historical time. 3. Precarious work and care: tracing legal regulation. 3.1. Sorry we missed you: social depletion from fiction to reality. 4. Final remarks. 5. References. 


\section{INTRODUCTION}

In recent years, the debates about the marketization of society have shed light upon disruptive dimensions of capitalist societies. As market reasoning and market apparatuses reach an increasing number of goods, ranging from education, health care and warfare, a concern rises whether social life can still produce the conditions for democratic governance and realization of human rights and, though not less important, whether the marketization of almost all aspects of life exacerbates economic inequality. A leading voice in this critique, Michael Sandel has questioned the progressive transformation of societies that use market as a tool to exchange goods to become societies in which the market ethos shapes nearly every domain of the social and the political. ${ }^{2}$

It is hardly surprising that social theorists have come to announce the contemporariness of Karl Polanyi's Great Transformation to account for the rapid degeneration of social bonds and the parallel rise in economic inequality. What these theorists recall is Polanyi's indication that the ascension of capitalist market economy is best understood within the logic of a double movement: on the one hand, the periods of State-regulated markets are those in which the conditions for the reproduction of social life - e.g. decent wages, social welfare - are minimally observed; on the other hand, historical moments characterized by the imperative of unbounded markets

2 SANDEL 2012. 
are the ones associated with diminishing social welfare and a general depletion of human life and natural environment. ${ }^{3}$

It is important to observe this understanding is not restricted to epochs of economic malfunctioning and other production-related variables deficits, as the 2008-2009 economic crisis could indicate. In fact, according to Polanyi's argument, the commodity-form feature of the capitalist mode of production personifies core values that, within specific historical conditions and contradictions, finally dismantle community values such as solidarity and care. ${ }^{4}$ Here lays, according to Nancy Fraser, one the most salient features of Polanyi's argument, and a most useful one to social theory's approaches towards the political dimensions of contestation. ${ }^{5}$

The commodification of life must not solely be put in terms of the broad expansion of market axioms - individualism, efficiency and negative freedom. Rather, and more importantly, what seems to be at stake falls back to the not so evident material conditions upholding productive structures the building blocks of personal character, to recall Richard Sennett's insight. ${ }^{6}$

Aspects of contemporary transformations of labour regulation - to which sociologist Ricardo Antunes refers to as the uberization of labour - and the dwindling provision of public services in various countries are but two indications of much greater changes in the social arena working in tandem to produce renewed mechanisms of economic inequality and social

3 FRASER 2011; FRASER 2017. See EBNER 2015 for a comparison between Polanyi's and Habermas' intake on the expansion of market coordination onto non-market coordinated social spheres.

4 POLANYI 2001.

${ }^{5}$ FRASER 2011.

${ }^{6}$ SENNETTT 1998. 
depletion. ${ }^{7}$ The hundreds of millions of workers left at the margins of legal recognition fall into the category of informal employment - defined as "the absence of formal contracts, rights, regulations, and bargaining power."

Once legal systems intermediate the extent to which market-reasoning will prevail in specific social arenas, it is worth examining how such an intermediation takes place in contexts of diminishing welfare apparatuses. This entails concerns whether basic social rights presently undergo a reframing process so as to absorb hegemonic claims of the primacy of market reasoning and, though not less relevant, to inquire about law's overall capacity to uphold communitarian values responsible for keeping the social fabric in a position to challenge the acceleration advocated by market enthusiasts.

The aim of this article is to investigate how contemporary capitalist societies, in particular its ability to replicate the conditions for the exploration of labour, can be understood through the lenses of historical and sociological analyses of law. Our main discussions will rover around two research objects: the first is the uberization of labour and the second is the specificities of care work. While these do not exist in completely different universes - as, for example, both entail forms of precarization and exploitation -, there is room for dedicated analysis for each. Uberization

\section{ANTUNES 2018.}

${ }^{8}$ DAVIS 2006, 181.

9 OST 1999. François Ost's work puts forward a historical interpretation of how legal systems institutionalize specific frames of social time in order to produce equilibrium between stability and change. It is nonetheless important to stress what the author names threats to law's task of similarly providing stability and openness to innovation. In this interplay, memory and forgiveness, promise and questioning, compose distinct times in which operations of connection and disconnection may assist in the institutionalization of time or disengage past commitments to make room for future pasts. 
accounts for, and yet is not reduced to, contemporary forms of labour that virtually allocates all risks and social costs of economic activity to the service provider. ${ }^{10}$ It provides fertile ground for understanding possible disruptive dynamics of expansion of market reasoning and the contraction of welfare provisions and basic rights. ${ }^{11}$ On the other hand, care work brings to the fore historical exploitation arrangements - class, gender, nationality - and their endurance in renewed fashions. ${ }^{12}$

The article sets off with an updated interpretation of Polanyi's insights by recent works of Nancy Fraser. In sequence, the problem of historical time will be considered to clarify a definition of law that entails the institutionalization of social time, and how contemporary times, immersed in the expanding movement of marketized social spheres, poses nonnegligible threats to law's ability to govern life. Though exclusively, it draws upon the philosophical contributions of François Ost about the time of law. Finally, the last part benefits from Ken Loach's Sorry we missed you, a 2019 movie that explores the contradictions of contemporary labour relations, to suggest the need to apprehend present legal problems within socialhistorical dimensions of the legal phenomena whereon the safeguard of individuals and groups is necessarily the defence of a proper time for law.

\section{CONTEXTUALIZING SOCIAL-LEGAL CRITIQUE IN TIMES OF CRISES}

10 KREIN, ABÍLIO, FREITAS, BORSARI and CRUZ 2018; FLEMING 2017.

11 ANTUNES 2018; FLEMING 2017.

${ }^{12}$ HIRATA 2016; FRASER 2016; PATEL and MOORE 2017. 
Efforts to compose an open appreciation of capitalist societies will in a way or another refer to the contemporary in terms of multiple parallel crises. ${ }^{13}$ The crash of the hegemony of the sovereign nation-State ${ }^{14}$, the fragmentation of social bonds, the end of politics propagated by defenders of the liberal consensus $^{15}$, on-going class exploitation crisscrossing gender and racial modes of violence, the post-constitutional ambience of self-regulated legal subjects defying collective constitutional designs ${ }^{16}$ and, last but not least, the environmental collapse anticipating future hazards, altogether comprise pieces of the contemporary that cast a shadow over projects of emancipation and struggles for justice. ${ }^{17}$

${ }^{13}$ For a comprehensive account of the paradigmatic transition both in science and society, in multiple scales and with particular focus on social-legal perspectives, see SANTOS 1995. ${ }^{14}$ Contemporary debates about the role of constitutionalism - its principles and institutions - in the international realm highlight the challenges faced by statehood when confronted with the impacts of financial markets, modern technologies and global economic crises. Consequently, its ability to safeguard basic fundamental rights is severely questioned. Supranational forms of governance gain momentum, providing grounds both for the increment of States' sovereign powers or its gradual substitution for non-constitutional schemes. For an acute appreciation of the subject, see MANGIAMELI 2019.

15 Probably one of the most discussed versions of the teleology of universal history has been put forward by Francis Fukuyama. See HARTOG 2015, 36.

16 TULLY 2007.

${ }^{17}$ According to FRASER 2011, 137: "With the global financial system teetering, worldwide production and employment in free fall, and the looming prospect of a prolonged recession, the economic aspect of capitalist crisis is impossible to ignore. But the same is true of the ecological aspect, given global warming, worsening pollution, resource exhaustion, and new forms of biocommodification that penetrate nature's very core. Then, too, the social dimension of crisis is increasingly salient - witness the devastated neighbourhoods, displaced families, and war - and disease-ravaged communities that crisscross our planet of slums. Nor can one overlook the political dimension: the crisis, first, of the modern territorial state; second, of the latter's would-be regional successors, above all the European Union; third, of US hegemony; and fourth, of the institutions of 
The United Nations publication World Social Report 2020 shows that income inequality has increased in most nearly all countries. It reveals that the richest one per cent of the global population have increased their income in the past three decades, while the bottom 40 per cent earned less a quarter of the overall income. The study places technological innovation, climate change, urbanization and international migration at the position of the driving forces of augmented inequality. ${ }^{18}$ Similarly, the World Inequality Report 2018 reveals that the elevated economic inequality varies significantly across regions; for example, the share of net national income accounted for the nation's top 10 per cent earners is on average 37 per cent in Europe, while in countries like Brazil it is about 55 per cent. ${ }^{19}$

In dialogue with this background, social theorist Nancy Fraser questions "how to conceptualize crisis as a social process in which economics is mediated by history, culture, geography, politics, ecology and law?". ${ }^{20}$ To put it differently, and to bring Fraser's perception closer to the underlying argument of this paper, one could reason that the very way crises are framed ought not to disregard the specificity of the economic conditions under which life reproduces itself. This appreciation seems just as relevant to understand how emancipatory struggles frame their transformative intents. It is, once and again, Polanyi's double movement what calls Fraser's attention:

global governance - all of which lack the imagination to envision solutions and the will and the capacity to implement them."

18 UNITED NATIONS 2020.

${ }^{19}$ UNITED NATIONS 2018.

${ }^{20}$ FRASER 2011, 138. 


\section{Henrique Weil ILABOUR, SOCIAL REPRODUCTION I ISSN 2675-1038}

'On its face, the distinction between embedded and disembedded markets has much to offer to critical theorizing. For one thing, it points beyond economism, to an expansive understanding of capitalist crisis as a multifaceted historical process, as much social, political, and ecological as economic. Thematizing the commodification of nature, Polanyi integrated the ecological dimension, while also recognizing social disruption and political stalemate as constitutive aspects of capitalist crisis. In addition, his approach points beyond functionalism. Centering his account on the double movement, he gave pride of place to the projects of social actors-and to the collisions among them. ${ }^{, 1}$

Fraser's identification of economism ${ }^{22}$ as a key limiting factor for emancipation struggles helps to bring to the surface the implications of both embedded markets, on its way immerse in non-economic institutions and subject to non-economic rules, such as fair price and fair wage, as well as disembedded markets, unchallenged whenever put against extra-economic constraints and governed by the laws of the free market. The author's multiscaled justice perspective, which encompasses the triple dynamics of redistribution, recognition and representation ${ }^{23}$, repositions Polanyi's double movement in critical lenses as a strategy to illuminate normative deficits that, in their turn, reproduce and sharpen power asymmetries.

${ }^{21}$ FRASER 2011, 143.

22 A similar approach of the blinding effects of economism, although fashioned around a bourdieusian interpretation of capitals, can be found in JODHKA, REHBEIN and SOUZA 2018.

23 FRASER 2010. 
Polanyi's Great Transformation displays a vigorous exploration the increasing dominance of the economic sphere over all other different regulations of social life. In the nineteenth century, the economic autonomy of market was achieved by a process of disembeddedness of all sources of external control that stems from the productive unity. As three objects - labour, land and money - undergo transformations towards their commodification, their social connotations lose all standing force and falls inside the domain of the free market. From here, the conditions for the disintegration of the social fabric are set in motion.

The interplay between regulation and autonomy consists in a joint operation involving state and society. Every ethical constraint historically placed upon markets has sprung from social institutions - family and work, for example - already embedding forms of discrimination that would become the driving forces backing legal regulation. Therefore, on the one hand, groups deprived of representation are left unprotected and subject to multiple forms of violence, whist, on the other one, embedded markets tend to adopt one-size-fits-all models of recognition that produce renewed schemes of violence. ${ }^{24}$ Once "the meanings and norms that have served to embed markets have often been hierarchical and exclusionary" 25 , the actual result is the protection of some people at the prejudice of others.

Law plays decisive roles both in recognizing forms of inequality and violence, and thus introducing normative agendas in the form of constitutional arrangements and rules capable of remedying long-standing injustices and prejudices against minority groups. Likewise, law upholds forms of inequality and violence by denying real legal subject status of individuals and groups - sometimes despite their formal recognition in

${ }^{24}$ FRASER 2011.

${ }^{25}$ FRASER 2011, 147. 
legislation - or by misframing legal recognition in disruptive ways their identities. Therefore, one cannot expect to reckon the sources of violence and injustice in general without a sustained account of how legal categories, norms and institutions interact with the historical, economic and social ambiences.

\subsection{The present of historical time}

The question of historical time is of central importance to our approach. Every single concern raised by demands of flexibilization of labour relations, management of the gig economy and the centrality of care work to provide social safety nets is likewise a distress about the acceleration of productive time in capitalist societies. It is therefore necessary to inquire whether the time of the market can be reconciled with other temporalities sustaining social life.

On the one hand, law institutionalizes social time whilst social time too institutionalizes legal institutes and practices; on the other one, political projects of collective life that aim to sustain meaningful lives to all (modern constitutionalism being the primary locus for such projects ${ }^{26}$ ) are destined to face the challenge of integrating multiple, sometimes conflicting temporalities, so as to allow proper balance between duration and transformation of social life. ${ }^{27}$

There is compelling reason to investigate how legal doctrine, institutions and norms relate with historical transformations of social time. Initially, in a concise reminder of significant developments in the field, suffice it may

26 TULLY 1995.

27 OST 1999. For an examination of the foundations of the modern conception of human rights and the development of its epistemological framework, see BRANDÃO 2019. 
be to recall the inputs from legal historians who take on postcolonial studies to explore how law mediates distinct forms of racial, gender, class and environmental violence nested in institutional frameworks such as the State and the market. ${ }^{28}$ International lawyers have given their share of contributions when they intersected critical analyses with time-honoured constituents of the law of peoples such as sovereignty, State recognition and legal subjectivity. They highlight the ambivalences of regulation and emancipation from colonial/imperial enterprises to contemporary economic debt poor countries. ${ }^{29}$

In addition, others draw attention to Enlightenment ethos of universal history and its rational subject as the two building blocks of the modern perception of temporality. Their association grant a specific version of social hierarchy, patriarchy and racial determinism to posit a matrix of linear historical teleology that idealizes European societies at the pinnacle of human progress. ${ }^{30}$ Contrasting with traditional historiographical interpretations, these critical analyses emphasize how modernity entails a myth ${ }^{31}$ about the

\section{BAXI 2005.}

29 ANGHIE 2004. For an analysis both of the literature critical legal history and the ambivalent status of the Third World in the international discipline, see AFONSO and MAGALHÃES 2013.

${ }^{30}$ In Enrique Dussel's The Invention of the Americas, Hegelian philosophy - and others, such as Kant - plays a key part in the formation of modernity. Despite the German philospher's claim that "the discovery of America is not a determinant of modernity", Dussel contends that "the experience not only of discovery, but especially of the conquest, is essential to the constitution of the modern ego, not only as a subjectivity, but as subjectivity that takes itself to the center or end of history." DUSSEL 1995, 25.

31 'This claim that the conquest is 'for the good of all' and of 'great benefit' for the dominated, vanquished one, perfectly expressed the myth of modernity. One defines one's own culture as superior and more developed and the other as inferior, crude, barbaric, and culpably immature. While one culture may be superior to another in many aspects, the critical observer realizes that the criteria of this superiority are always qualitative and so uncertain in their application. Even the violence inflicted on the Other 
justification of violence as a means to elevate the inferior other to the hallmarks of the civilized peoples. These studies have been challenging wellestablished cannons of legal historical tradition. ${ }^{32}$

In any case, against the backdrop of the uniformity that characterizes apprehensions of time that dominated the field in the XIX century, and considering postcolonialism's critique of institutionalized violence, legal history has benefited a great deal from social scientists' insights about the plurality of social times. Braudel's longue durée and Lévy-Strauss' conception of cultural progress are examples of the cross fertilization of knowledges, historical and anthropological in this case, leading to renewed, denser conceptions of social time. ${ }^{33}$

To avoid tempting simplifications of historical time - as in the case of Eurocentric formulations of modernity -, we fall back on Reinhart Koselleck to consider the constituent tensions of historical time. On one end of the spectrum of possible histories one encounters the space of expectation, "present past, whose events have been incorporated and can be remembered", while, at the other end, lays the borizon of expectations of "the future made present; it directs itself to the not-yet, to the nonexperienced,

is said to serve the emancipation, utility, and well-being of the barbarian who is civilized, developed, or modernized. Thus after the innocent Other's victimization, the myth of modernity declares the Other the culpable cause of that victimization and absolves the modern subject of any guilt for the victimizing act." DUSSEL 1995, 64.

${ }^{32}$ For example, they expose modern constitutionalism's standards of rights have come to embrace an "empire of uniformity" that surpasses ancient constitutions of peoples. It embeds premises of historical time structured in the passing of evolutionary stages, a political format of the peoples around the homogeneity of the sovereign power and the nation and a foundational moment that forge the standard for judging different cultures. TULLY 1995; TULLY 2007.

${ }^{33}$ HARTOG 2015. 
to that which is to be revealed" 34 . The two categories dialogically interact from the stand point of the lived experiences to establish the possibilities of the times yet to be lived. Somewhere in between experience and expectation the present emerges to give meaning to the future:

'[...] it is possible to see that what is expected of the future is evidently limited in a manner different from what has been experienced in the past. Cultivated expectations can be revised; experiences one has had are collected. Today it can be expected of experiences that they will repeat and confirm themselves in the future. On the one hand, one cannot experience an expectation in the same way today. The prospect of the future, raising hopes or anxieties, making one precautionary or planful, is certainly reflected within consciousness. [...] Experience is specified by the fact that it has processed past occurrence, that it can make it present, that it is drenched with reality, and that it binds together fulfilled or missed possibilities within one's own behaviour. ${ }^{35}$

In contemporary societies, it could be argued that both historical and social times are to a certain extent absorbed by the commands of a protracted present. Citizens of a world where so much happens in each instant and yet with so little time to extract any social meaning are full-time members of societies governed by rising risks. Paradoxically, it provides this accelerated present with a sense of continuous expansion: if the past no longer offers lessons to today's problems and has exhausted all its promises, and if the space of experience is jam-packed with objects of the empire of the ephemeral, to

${ }^{34}$ KOSELLECK 2004, 259.

${ }^{35}$ KOSELLECK 2004, 261. 
bring Ost's recollection of Lipovestky ${ }^{36}$, than what springs from this insulated present is nothing less than the impossibility of a durable legal time.

The production of lasting social memories that are strong enough both to sustain collective life for individuals and communities depends whether the space of experience is capable to provide normative regulation with axiological content. How societies praise a specific activity, such as labour or care, the ways in which it shapes both individual and collective memories, is determinant to the recognition not just of its legal status, but also paramount to the allocation of regulatory priorities in terms of welfareoriented policies. This mediates the approximation of marketization to other life's spheres: one of law's most prominent functions is to contribute to the institutionalization of the social, reflects François Ost, "more than interdicts and sanctions, as it was once believed to be, or calculus and management, as is thought to be in these days, [law is] a fabric of operatory fictions that express the meaning and value of life in society." 37

Here emerges the significance of law: it institutionalizes norms to strengthen social bonds and to offer individuals and groups indispensable points of reference to their identities and autonomy. As with individuals, labour uberization - reads precarization - may impose unbearable amounts of pressure to the construction of what sociologist Richard Sennet has termed personal character. Built and sustained by long-term commitments, it acquires meaning as individuals choose those life experiences that elevate their own lives, while discharging the ones that do not. Without those personal traits, asks Sennett, "how can a human being develop an identity

36 OST 1999.

37 OST 1999, 13-14 (free translation). 
narrative and a life history in a society composed of episodes and fragments?". 38

In this sense, it is worth locating the status of historical time with the assist of what historian François Hartog named regimes of historicity. In order to challenge the repercussions of historian's relations with time, there is the need for "an heuristic tool, helping to better grasp, not the time, all times or time totality, but chiefly the moments of crisis in time". ${ }^{39}$ Consequently, the idea of regimes of historicity aims to highlight the evidences of loosening articulations between past, present and future. Speaking to Hannah Arendt's inquiry on the gap between the past and the future brought about the legacy of $20^{\text {th }}$ century totalitarian regimes, Hartog asks: "is there a relation between a forgotten or overly recollected past, between the future that has vanished from the horizon or between a threatening destiny, a continually consummate present in an almost static or never-ending immediacy, if not eternal?". 40

\section{PRECARIOUS WORK AND CARE: TRACING LEGAL REGULATION}

The aforementioned insights compose part of the framework upon which critical legal analyses have been standing upon over the past few decades. Nevertheless, and recalling Fraser's insights about the need to go beyond the economic rationale that rules ever expanding goods of life, the elements

38 SENNETT 1998, 27.

${ }^{39}$ HARTOG 2015, 37 (free translation).

${ }^{40}$ HARTOG 2015, 38 (free translation). 
of particular relevance to our case are the uberization of labour and care work. It is time to turn to them.

In capitalist societies, work appropriation - be it human or extrahuman work $^{41}$ - is a chief component of wealth accumulation and to the preservation of economic inequality in rising figures. Although this is not the adequate place to expand the argument, and given the amount of work already put into action on how expropriation of work structures capitalist societies $^{42}$, there is a pressing need to explore how a critical appreciation of current forms of work appropriation - namely the so-called uberization of work and the exploitation of care work - could interact with Fraser's revival of Polanyi as a means to produce historically situated analyses of the interplay between regulation and emancipation.

Mike Davis observes that "increasing competition within the informal sector depletes social capital and dissolves self-help networks and solidarities essential to the survival of the very poor - again, especially women and children." 43 An abysm is formed between the idealized benefits of market-led social life and the growing disenfranchisement of populations worldwide. It is then a task of critical legal studies to scrutinize legislation

${ }^{41}$ PATEL and MOORE, 2017, 95: “[...] capitalism sets in motion not just human work and not just agriculture and resources - but how they fit together, and the relations that bind human and extrahuman work at every turn."

42 The most discussed version of this understanding obviously falls back to Karl Marx's theory of primitive accumulation. For an interesting approach to Marx's original thesis and an effort to highlight its general applicability in the present, see READ 2002. In effect, in Marxist tradition, as Read contends, "Marx's theory of primitive accumulation can be read as a contribution to an understanding of 'materiality' of social relations and subjectivity, and ultimately, despite appearances, to an understanding of the capitalist mode of production itself." READ 2002, 25. For an interpretation of primitive accumulation in harmony with the expropriation of extrahuman work, see MOORE 2017.

${ }^{43}$ DAVIS 2006, 184. 
and jurisprudence about the specific historical forms of exploitation that places work as the defining building block of social fabric.

According to Raj Patel and Jason Moore, the rise of capitalism via the transformation of socioecological relations can be described as one in which cheap goods are integrated in a web of life positioned to serve the purposes of wealth accumulation. In their view, cheapness represent "a set of strategies to manage relations between capitalism and the web of life by temporarily fixing capitalism's crises", violently mobilizing all kinds of work - human and animal, biological and geological - "into circuits of production and consumption"44. Moving from one frontier to the next, beginning with experimental techniques in sugar cane production in Ilha da Madeira in the final decades of the fifteenth century - integrating enslaved populations in the production cycle -, exploring seventeenth and eighteenth centuries transoceanic slave trade from Africa to the Americas, to modern wage labour in industrial societies,

'Capitalism's frontiers always lie firmly within a far larger world of life making. For capitalism, what matters is that the figures entered into ledgers - to pay workers, to supply adequate food to workers, to purchase energy and raw materials - are as low as possible. Capitalism values only what it can count, and it count only in dollars. Every capitalist wants to invest as little and profit as much as possible. For capitalism, this means that the whole system thrives when powerful states and capitalists can reorganize global nature, invest as little as the can, and

${ }^{44}$ PATEL and MOORE 2017, 22. 


\section{Henrique Weil ILABOUR, SOCIAL REPRODUCTION I ISSN 2675-1038}

receive as much food, work, energy, and raw materials with as little disruption as possible. ${ }^{, 45}$

Governing time, more specifically modern time, involved administering forms of control and violence not only in industrial European contexts; it turned out to be essential the colonial enterprise. Resistance to this imposition was racialized as lazy, and from Indigenous peoples in the Americas to Aborinals Australians, a logic of simplification was imposed upon "holistic sense[s] of production and a connection to wider worlds of life and society." 46

Work is part of a complex network that provides capitalist economy with cheap components. The combination of these elements aims at the acquisition of functional status in the overall production of value. In this scheme, the concern for labour productivity was sharpened by assuming time as the distinctive attribute structuring life, space and nature.

\subsection{Sorry we missed you: social depletion from fiction to reality}

Movie director Ken Loach, in the 2019 Sorry we missed you, once again ${ }^{47}$ explored the universe of the British working class. The movie offers an intimate family drama amidst the perils of the gig economy. Ricky and Abby's family are in need to get out of financial distress when Ricky starts working as a delivery driver, whereas Abby is submitted to long daily commutes to home assist elderly clients with their basic needs. The couple sell Abby's car

45 PATEL and MOORE 2017, 21.

46 PATEL and MOORE 2017, 96.

47 The 2016 Me, Daniel Blake is another example of Loach's interest in portraying British working class in contexts of social vulnerability. 
to allow Ricky to finance a new delivery van and fulfil his expectations to work as his own boss.

The family quickly finds their lives turned upside down. Ricky is pressed against the wall by an unrelenting work timetable, an unmerciful supervisor and the demands of their two teenage children. Abby, in her turn, struggles with the physical and psychological strains of a care worker and the parallel supervision of the offspring and household chores. While the history unfolds, a combination of financial debt, emotional and physical anguish and strict work control disrupts the expectations of personal self-sufficiency and professional satisfaction of the whole family.

The movie opens up a window of visibility to the reality of perhaps hundreds of millions of informal workers about whom Mike Davis referred to as surplus bumanity ${ }^{48}$. Ricky's is the case of the promise to become an empowered entrepreneur thriving in the economic waves of innovation, a promise that attracts unemployed and underemployed individuals worldwide. The hope to reap the benefits of the digital revolution, with its on-demand services enabled by GPS technology equipping smartphones, places companies such as Uber and Airbnb at the top of twentieth -first century's economic race. The assembly of trust and expertise in these peerto-peer platforms creates an inviting atmosphere for individuals to become, for example, providers of urban transport or deliverers of goods. Above all,

${ }^{48}$ DAVIS 2006, 176-178: "Since 1980, however, economic informality has returned with a vengeance, and the equation of urban and occupational marginality has become irrefutable and overwhelming: informal workers, according to the United Nations, constitute about two-fifths of the economically active population of the developing world. [...] Altogether, the informal working class (overlapping with but non-identical to the slum population) is about one billion strong, making it the fastest-growing, and most unprecedented, social class of earth." 
the perspective of being ones' own boss boosts confidence and expectations about professional success. ${ }^{49}$

If, in Ricky's turn, the uberization of work is existent in every single aspect of his entrepreneurial dream, from bearing all work-related costs to mental and physical collapse, it is Abby who endures a mostly neglected form of social exploitation. As Patel and Moore point out, the marginal status of care work and care workers are not solely the result of an economic system that restructures exploitation arrangements from crisis to crisis, but, perhaps puzzlingly, the very sustaining framework whereon social reproduction is staged. ${ }^{50}$ Largely described as a "set of material and psychological practices concerned with supplying concrete responses to other's needs" 51 , care work has historically been executed by women in the domestic space known as the private sphere. With the development of care-related professions, a mass insertion of women in the job market was noted in countries such as Brazil, France and Japan. It also comprises a sexual and international division of work embracing a network of migrant workers originally from Asia, Africa, Latin America, the Caribbean and Eastern Europe to supply cheap labour in the USA, Canada, Western Europe and Japan, as recent studies have revealed. ${ }^{52}$

Another characteristic of care work is its highly racialised status. In Brazil, for example, "care work in both homes and institutions for the elderly is carried out by Brazilians, although domestic work was done by African slaves and their descendants until the end of the $19^{\text {th }}$ century". "53 Given the

49 THE GARDIAN 2015.

50 PATEL and MOORE, 2017.

${ }^{51}$ HIRATA 2016, 54.

${ }^{52}$ HIRATA 2016.

${ }^{53}$ HIRATA 2016, 56. 
fact that different societies experience diverse forms of discrimination, in the British context Abby provides services not only to aging individuals who have been put aside by their families, but also to disadvantaged individuals of all ages. In addition to day-to-day episodes of racism sustained by racialised deeper social structures such as the State, labour market or criminal justice ${ }^{54}$, discrimination in salary by the non-recognition of their qualifications discloses the structural economic disadvantages of vast swaths of the population in countries like Brazil.

Having reached a historical peak of $41,4 \%$ of its employed population inserted in informal labour schemes in $2019^{55}$, Brazil stands out in the global panorama as a study case of how legal regulation of labour is a key variable if one wishes to make sense of the dynamics of injustice stemming from both embedded and disembedded markets. Unfortunately, the country is far from being an exception. Loach's film goes a long way to explore the contradictions of contemporary gig economy and its effects upon social institutions such as work, care and family. As the plot develops, what Antunes has called new service proletariat turns out to be an appropriate description of both Ricky and Abby's predicament: informal workers with little or no security or benefits who in the past decades have given rise to a new category of work class - the precariat. In addition, as Fleming stresses, one notes how employment goes through a process of individualization wherein the costs of labour are transferred to the employee with the

54 ALMEIDA 2019. In Almeida's study, racism is perceived a structural element of economic organization and social politics. Rather than a manifestation of prejudice, racism is viewed through normality lenses whereon the sense, the logic and the technology to the reproduction of the inequalities and violence shaping life in contemporary societies. In spite of the array of historical and cultural racial references, the sources of modern racism is located in colonial practices of XVII and XVIII centuries that culminated in XIX century pseudo-scientific justifications of racial inferiority.

55 INTITUTO BRASILEIRO DE GEOGRAFIA E ESTATÍSTICA 2019. 
assistance of "labour-on-demand business models, self-employment, portfolio careers and zero-hours contract." ${ }^{, 56}$

The legal form shaping these services provisions include, for example, the zero-hour contract hours in Britain, the Italian voucher-based work ${ }^{57}$ and the intermittent work contract in Brazil ${ }^{58}$. Nevertheless, the new service precariat cannot be dissociated from the uberization of labour, "a ruthless entrepreneurial modus operandi aimed at generating more profit and increasing the value of capital through the forms of precarious labour". ${ }^{9}$ In this sense, and moving beyond the rather interesting discussion concerning the precariat's status as a distinguished social class ${ }^{60}$, the uberization of work resonates deeply in contexts of dwindling protection of rights brought about by the deregulation of labour market and decreasing welfare social protections $^{61}$.

Public discourse in modern societies tends to deviate from deeper scrutiny about the structure and reproduction of inequality. Its overall assumption about individuals' equal aptitude to pursue their interests fuels meritocratic justifications of inequality and disguises social constructions of social classes' privileges. Nothing less than a mystery of modern societies unfolds

56 FLEMING 2017, 2.

${ }^{57}$ ANTUNES 2018; KREIN, ABÍLIO, FREITAS, BORSARI and CRUZ 2018.

58 BRAZIL 2017. A type of formal work contract, intermittent labour was introduced in 2017 in Lei 13.467 (the so-called Brazilian work reform) and is characterized by a relation in which the worker must remain at their bosses' disposal, put on hold and summoned upon whenever called on. They are paid only for the hours the actually worked, and not the waiting time spent.

59 ANTUNES 2018.

${ }^{60}$ A critique of the concept in its apparent inadequacy to elaborate Southern perspectives of precarious labour is found in MUNCK 2013.

${ }^{61}$ KREIN, ABÍLIO, FREITAS, BORSARI and CRUZ 2018. 
here, "the fact that they are not individuals competing under conditions of equal opportunity, but rather societies that perpetuate unjust class privileges", ponders sociologist Jessé Souza and collaborators. ${ }^{62}$ Recalling Fraser's assertion about the pitfalls of economism, by the same token one must be vigilant about how differences in socialization may shape access to labour market with distinct levels of income.

The adoption of this bourdieusian explanation posits economic capital as but one of the constituents of social reproduction in capitalist societies. Even though economic capital is the most visible, social reproduction is likewise dependent on the quantity of "inherited and acquired capital" that takes the form of, for instance, cultural capital. Usually recognized as accumulated knowledge, "there is no function either in the market or in the state that can be fulfilled" ${ }^{64}$ deprived of it; its transmission occurs inside the family core, be it more visible - economic - or less visible - cultural -, to regulate not just how social classes are distinguished between one another, but mainly by dictating what chances individuals will have in succeeding in the world.

The problem of reproduction of life in capitalist societies also involves turning to the ways unpaid work is expropriated from workers to forge, alongside work exploitation and nature commodification, the triple division of work. The bounds of what counts as payable work are of interest here, for the practice of offering free gifts to the economy must rely upon regulatory norms targeted at disciplining forms of work in hierarchical scales

${ }^{6}$ JODHKA, REHBEIN and SOUZA 2018, 84.

${ }^{63}$ JODHKA, REHBEIN and SOUZA 2018, 85.

${ }^{64}$ JODHKA, REHBEIN and SOUZA 2018, 85. 
in which formal and informal work mediate the conditions of human subsistence.

\section{FINAL REMARKS}

This investigation intended to provide an estimation of how law, the sole entity responsible for the normative institutionalization of social time ${ }^{65}$ - that means to say, the product of collective constructions of history, the product of contingent combinations of memory and forgetting, of institutionalized promises and where postulants work to destabilize such promises - presents itself in a context of a totalizing market ethos imposing increasingly disruptive pressures on the reproduction of life.

An attempt to characterize the present time was pursued with the assist of a multi-layered analytical framework. Starting with the revival of Polanyi's arguments, this article considered the implications of marketization in social spheres such as labour relations and regulations. By structuring legal regulation in an historical critique of social reproduction in capitalist societies, it intended to present an account of how contemporary forms of labour exploitation act to prevent social time from producing meaningful contexts in which individuals and groups share a common life, one wherein values such as affection and dignity play decisive roles.

The uberization of labour discloses the impositions of market time over social life. Atomized individuals seeking personal and professional realization in ever changing virtual environments are left unassisted, bearing the burdens of failure as the risks are absorbed in their entirety. Unable to experiment satisfaction and self-realization, the new precariat find themselves

${ }^{65}$ OST 1999. 
stuck in a place where no experience can be lived to its full, for in such a place the time of market reigns. Without meaningful life narratives, their characters are reduced to a collection of service apps. In addition, the social fabric is kept together by a mass of care workers; the convergent point of multiple forms of violence and deep-rooted prejudices, care work is an example of how cheap labour is produced, appropriated and sustained even in contexts of professional recognition.

In sum, what we may retain from the above elements reflect a preoccupation. It has to do with law's ability to resist the specific conditions of time of contemporary capitalist societies. And the reason is this: when confronted with the pressing anxieties of this day and age, the very institutions entrusted with providing individuals with the degree of recognition indispensible for sustained narratives of life - e.g. welfare provisions and labour regulation - may themselves be going through transformations that, at the end of the day, deinstitutionalizes the means of social reproduction in all life spheres that are attractive to market demands. When legal and market times join forces, one can hardly envision any trace of dignity and humanity to Ricky and Abby's family future.

\section{REFERENCES}

AFONSO, Henrique Weil, MAGALHÃES, José Luiz Quadros, “The Third World, History and International Law", Brazilian Yearbook of International Law, 2013, 107-126.

ALMEIDA, Silvio, Racismo Estrutural, São Paulo, 2019.

ANGHIE, Antony, Imperialism, Sovereignty and the Making of International Law, Cambridge, 2004. 


\section{Henrique Weil |LABOUR, SOCIAL REPRODUCTION | ISSN 2675-1038}

ANTUNES, Ricardo, “The New Service Proletariat”, Monthly Review, 2018, 23-29.

BAXI, Upendra, "Postcolonial Legality", in SCHWARZ, Henry, RAY, Sangeeta (eds.), A Companion to Postcolonial Studies, Oxford, 2005, 540-555.

BRANDÃO, Claudio, "The roots of human rights: the epistemological turn provoked by Francisco de Vitória", Humanities and Rights Global Network Journal, 2019, 7-20.

BRAZIL, Lei no. 13.467, de 13 de julbo de 2017, http://www.planalto.gov.br/ccivil_03/_ato2015-

2018/2017/lei/113467.htm, accessed 15 February 2020.

DAVIS, Mike, Planet of Slums, London, 2006.

DUSSEL, Enrique, The Invention of the Americas - Eclipse of "the Other" and the Myth of Modernity, New York, 1995.

EBNER, Alexander, "Marketization: Theoretical Reflections Building on the Perspectives of Polanyi and Habermas, Review of Political Economy, 2015, 369-389.

FLEMING, Peter, "The Human Capital Hoax: Work, Debt and Insecurity in the Era of Uberization”, Organization Studies, 2017, 1-19.

FRASER, Nancy, "A Triple Movement? Parsing the Politics of Crisis after Polanyi”, in: BURCHARDt, Marian; KIRN, Baj (eds), Social Analysis after 1989, London, 2017, 29-42. 


\section{Henrique Weil |LABOUR, SOCIAL REPRODUCTION | ISSN 2675-1038}

FRASER, Nancy, "Contradictions of Capital and Care", New Left Review, 2016, 99-117.

FRASER, Nancy, "Marketization, Social Protection, Emancipation: Toward a Neo-Polanyian Conception of Capitalist Crisis", in: Calhoun, Craig; Derluguian, Georgi (orgs), Business as usual: the roots of global financial meltdown, New York, 2011, 137-158.

FRASER, Nancy, Scales of Justice - Reimagining Political Space in a Globalizing World, New York, 2010.

HARTOG, François, Regimes de Historicidade: presentismo e experiências do tempo, Belo Horizonte, 2015.

HIRATA, Helena, "Care Work: a comparison of Brazil, France and Japan”, SUR, 2016, 53-63.

INSTITUTO BRASILEIRO DE GEOGRAFIA E ESTATÍSTICA, Pesquisa Nacional por Amostra de Domicílios Contínua (PNAD Contínua), September 2019, https://agenciadenoticias.ibge.gov.br/agencianoticias/2012-agencia-de-noticias/noticias/25534-desemprego-cai-para11-8-com-informalidade-atingindo-maior-nivel-da-serie-historica accessed 20 February 2020.

JODHKA, Surinder; REHBEIN, Boike; SOUZA, Jessé, Inequality in Capitalist Societies, New York, 2018.

KOSELLECK, Reinhart, Futures Past: on the semantics of historical time, New York, 2004. 
KREIN, José, ABÍLIO, Ludmila, FREITAS, Paula, BORSARI, Pietro, CRUZ, Reginaldo, "Flexibilização das relações de trabalho: insegurança para os trabalhadores", Revista do Tribunal Regional do Trabalho da $15^{\mathrm{a}}$ Região, 2018, 41-66.

MANGIAMELI, Stelio, "State, European Integration, and Globalization. New challenges for Constitutionalism", Humanities and Rights Global Network Journal, 2019, 161-206.

MOORE, Jason W., "The Capitalocene Part II: accumulation by appropriation and the centrality of unpaid work/energy", The Journal of Peasant Studies, 2017, 1-43.

MUNCK, Ronaldo, "The Precariat: a view from the South", Third World Quarterly, 2013, 747-762.

OST, François, Le Temps du Droit, Paris, 1999.

PATEL, Raj, MOORE, Jason, $A$ History of the World in Seven Cheap Things, Oakland, 2017.

POLANYI, Karl, The Great Transformation: The Political and Economic Origins of Our Time, Boston, 2001.

READ, Jason, "Primitive Accumulation: The Aleatory Foundation of Capitalism”, Rethinking Marxism, 2002, 24-48.

SANDEL, Michael, What money cannot buy - the moral limits of markets, New York, 2012. 
SANTOS, Boaventura Sousa, Toward a new common sense: Law, Science and Politics in the Paradigmatic Transition, New York, 1995.

SENNETT, Richard, The Corrosion of Character: The Personal Consequences of Work in the New Capitalism, New York, 1998.

THE GUARDIAN, The 'gig economy' is coming. What will it mean for work?, 25 July 2015, https://www.theguardian.com/commentisfree/2015/jul/26/will-we-getby-gig-economy accessed 6 February 2020.

TULLY, James, "The Imperialism of Modern Constitutional Democracy", in LOUGHLIN, Martin; WALKER, Neil, The Paradox of Constitutionalism: Constituent Power and Constitutional Form, Oxford, 2007, 315-338.

TULLY, James, Strange Multiplicity: Constitutionalism in an age of diversity, Cambridge, 1995.

UNITED NATIONS, World Social Report 2020 - Inequality in a rapidly changing world, https://www.un.org/development/desa/dspd/wpcontent/uploads/sites/22/2020/02/World-Social-Report2020ExecutiveSummary.pdf accessed 10 February 2020.

UNITED NATIONS, World Inequality Report 2018, https://en.unesco.org/inclusivepolicylab/sites/default/files/publication/ document/2018/7/wir2018-full-report-english.pdf accessed 10 February 2020. 